\title{
Effect of Entry into Socially Responsible Investment Index on Cost of Equity and Firm Value
}

\author{
Kijung Eom and Giseok Nam * \\ College of Business, Hankuk University of Foreign Studies, 107, Imun-ro, Dongdaemun-gu, Seoul 130-791, \\ Korea; kjeom@hufs.ac.kr \\ * Correspondence: gsnam05@hufs.ac.kr; Tel./Fax: +82-2-2173-3029
}

Academic Editor: Yongrok Choi

Received: 22 April 2017; Accepted: 25 April 2017; Published: 29 April 2017

\begin{abstract}
The purpose of this study was to identify the effect of a company's incorporation into the Socially Responsible Investment (SRI) index on its cost of equity (COE) and corporate value. The study collected and analyzed data about the four-year long changes of the component stocks of the Korea Exchange (KRX) SRI index from September 2010 to September 2013 to verify the correlation between the incorporation of the SRI index and the cost of equity or corporate value by using the Price-Earnings Growth (PEG), Modified PEG (MPEG) and Gode and Mohanram (GM) models for estimation of the implied costs of equity capital, as well as Tobin's $Q$ ratio. The analysis results failed to show any significant relation between the incorporation of the SRI index and the cost of equity capital. Also, no statistically significant correlation between the incorporation of the SRI index and corporate value was observed. However, at an early phase of introduction of the SRI index, the included companies revealed a negative correlation with the cost of equity. However, after changing the listed stocks, they showed a positive correlation with the cost of equity capital. All in all, this can be ascribed to a mixed presence of optimistic and pessimistic investors about CSR activities, or there is a possibility that the KRX SRI index might not correctly reflect the CSR activities of companies.
\end{abstract}

Keywords: CSR (corporate social responsibility); SRI(socially responsible investment); cost of capital; Tobin's Q

\section{Introduction}

The socially responsible investment (SRI) funds of Europe doubled from 1330 billion euros in 2005 to 2665 billion euros in 2007. Similarly, in the United States, SRI funds surged dramatically from 1650 billion dollars to 2098 billion dollars [1]. Such a rapid growth was driven by the participation of various institutional investors such as managers of pension funds. In Korea, the national pension fund invested 5539 billion dollars in the socially responsible investment as of the end of March 2013. Since joining the United Nations-supported Principles for Responsible Investment (PRI) Initiative (a recommended internal norm for responsible investment) in 2009, the National Pension Fund has included the Principles for Environmental, Social and Corporate Governance (hereinafter 'ESG') in its guidelines for exercise of voting rights, and increased its stake in SRI stocks by establishing the SRI team under the National Pension Fund Investment Office in order to improve the national pension funds' profitability and public interest. When institutional investors want to expand the SRI portfolio, the Korea Exchange (KRX)'s SRI Index is used as the guideline for portfolio expansion. Therefore, if companies are to be incorporated in the SRI index, it is expected to encourage the participation of institutional investors.

Unlike regular investments which only emphasize a financial aspect, the Socially Responsible Investment (SRI) is an investment that considers not only a financial facet but also a non-financial 
facet. Therefore, the SRI is an investment method that comprehensively considers non-financial aspects which have an influence on the sustainability of companies, such as environmental, social and corporate governance (ESG).

The concept of socially responsible investment derives from Corporate Social Responsibility (hereinafter, 'CSR'). Today, companies live in an open system where they constantly interact with the environment. Therefore, companies must pursue a sustainable development with their interested parties through the CSR for the sustainability and development of businesses. There are mixed viewpoints about the CSR; some say it can have a positive impact on corporate value, while others maintain that it has a negative influence. The optimistic opinion says that companies' CSR activities can improve corporate values by reducing potential conflicts with various interested parties $[2,3]$. On the other hand, the pessimistic opinion maintains that as companies' CSR activities can incur additional costs, it goes against their fundamental goal to maximize the interests of shareholders, which ultimately causes a drop in shareholder values [4]. However, recent studies have shown that companies' CSR activities incur costs at an early stage but eventually lead to enhancing corporate values [5]. If we examine the route of how a company' CSR activities will have influence on corporate values, the concerned company's CSR activities will reduce potential conflicts with many different interested parties, which lowers risks and improves profitability, or will increase voluntary disclosures, which reduces information asymmetry; the subsequently diminished cost of equity will lead to enhancing corporate values.

The purpose of this study is to analyze the correlation between the CSR activities, equity of cost, and corporate value, and has the following differentiated values compared to the other studies. First, the KRX SRI Index was used as the proxy variable of CSR activities of companies. The KRX SRI Index was used as the criterion for SRI portfolio expansion of institutional investors including the National Pension Fund. Given this, the KRX SRI Index can be considered as the representative index of CSR activities. Secondly, the SRI index used for this study was analyzed by separating the time of the introduction of the KRX SRI Index from the changing time of the list of the component stocks. The criterion for the incorporation to the KRX SRI index is in compliance with the market weighted index, and there are many conglomerates among those companies which were incorporated at the time of its new introduction. Therefore, it was necessary to analyze the influence at the time of introduction and at the time at which relevant portfolio items changed. Thirdly, this study analyzed the relation between CSR activities and the cost of equity and additionally verified how this affected the corporate value. Since a company's cost of equity influences its corporate value, there was a need to verify the influence of CRS activities on the cost of equity and corporate values at the same time.

The remainder of this study proceeds as follows: Section 2 introduces the previous studies. Section 3 explains the study's methods and models that were used to set up and verify the hypotheses. Section 4 presents the results of the study. Lastly, Section 5 draws a conclusion on the study results, and suggests the limitations of this study as well as the directions for future study.

\section{Previous Studies}

\subsection{Previous Studies on CSR and Financial Performance}

The viewpoints about the CSR can be divided in the opposing opinions: the optimists say that the CSR can relax conflict with the interested parties and increase corporate values, whereas the pessimists say that the CSR can incur additional costs and subsequently reduce corporate values. The previous studies on social responsibility suggested the opposing results in this context.

Among those previous studies that reported positive impacts of the CSR on corporate value, Pava and Krausz [4] discovered that a company with a higher environmental performance achieved a better financial performance than otherwise. Posnikoff [6] analyzed the excess returns between CSR activities and corporate performance and found that the CSR activities had a positive relation with corporate performance. Also, Waddock and Graves [7] discovered a positive relation between 
CSR activities and management performance and concluded that they were mutually influenced by each other. Orlitzky et al. [8] found a positive relation between environmental performance and financial performance of companies, and revealed that the CSR activities had a closer relation with accounting-based performance than with market-based performance. In South Korea, Kim [9] said in the conclusion that if a company with a higher share-holding ratio of large shareholders engages in CSR activities, its corporate value will be increased. Jang and Choi [10] analyzed the relation between CSR activities and financial performance, and the study results showed that CSR activities had a positive influence on corporate value.

In contrast, among those studies that indicated a negative impact of the CSR activities on companies, Wright and Ferris [11] offered the conclusion that because CSR activities had a negative influence on the wealth of shareholders, there was a negative relation between CSR activities and financial performance. Brammer et al. [12] analyzed the CRS components of the Experts in Responsible Investment Solutions (EIRIS) and the performances of companies incorporated in the Financial Times Stock Exchange (FTSE) index, and reported that there was a negative relation between the CSR components and corporate performance.

\subsection{Previous Studies on Corporate Social Responsibility and Cost of Equity Capital}

If one looks into the influence of CSR activities and the cost of equity, a study by Lambert et al. [13] discovered a negative relation $(-)$ between the level of voluntary environmental information disclosure and the cost of equity. Another study by Ghoul et al. [14] analyzed the relationship between the CSR activities and the implied cost of equity, and reported that as the CSR activity scores were getting higher, companies' costs of equity decreased. Among domestic studies on the cost of equity, a study by Jang and Choi [10] verified that there was a positive (+) relation between the CSR activities and the weighted average cost of equity. Another study by Cheon [15] reported that those companies which engaged in the CSR activities had a lower cost of equity than otherwise, and that there was a negative $(-)$ relation between the CSR activities and the cost of equity capital. Another study by Na et al. [16] analyzed the relation between the ESG performance grades and the cost of debt capital. According to the analysis results, there was a negative relation between the ESG performance grades and the cost of debt capital which was estimated by using the debt-interest costs, whereas there was a positive $(+)$ relation between the ESG performance grades and the cost of debt capital which was estimated by using corporate bond rating grades.

\subsection{Previous Studies on SRI Index}

Most studies on the SRI Index were conducted to identify the relation between investment performance and the cost of capital. Among overseas studies, a study by Jin et al. [17] targeted two SRI indexes in Japan to analyze the investment performances by comparing the index performance with the market returns. According to the results, the return rates of the Japanese SRI indexes were found to be lower than those of the market portfolio. Another study by Becchetti et al. [18] compared the return rates of those companies which were incorporated into the Dominican SRI index with those which were not, and reported that those incorporated into the SRI Index constantly showed a positive (+) excess return, while those otherwise had a negative (-) excess return. Another study by Schroeder [19] maintained that the SRI Index did not show a better return than the traditional benchmark index but had greater risks than the benchmark index. Ziegler [20] examined the impact of incorporating the Dow Jones Sustainability World Index on corporate value for European companies. As a result, the financial performance of the incorporated firms was not statistically significant. Oberndorfer et al. [21] observed returns when German firms were incorporated into the Dow Jones STOXX Sustainability Index and the Dow Jones Sustainability World Index. As a result, Dow Jones STOXX Sustainability Index did not show a statistically significant relationship with the rate of return, while the incorporation of the Dow Jones Sustainability World Index had a negative effect on the return. Among the domestic studies, a study by Lee Sang-won [22] verified that the KRX SRI Index had a better performance compared to 
the Korea Composite Stock Price Index (KOSPI) 200 Index. Another study by Park [23] verified the investment performance of the KRX SRI Index, and reported that the KRX SRI Index failed to show any better performance than the KOSPI Index, and neither the newly incorporated stocks nor the excluded stocks showed any significant differences in their investment performances. Another study by Park and Ok [24] targeted the KRX SRI Eco Index to analyze the effect of the incorporation into the index on corporate value, and reported that the incorporation into the KRX SRI Eco Index did not have any significant influence on corporate values. In contrast, another study by Lee and Go [25] set up those companies incorporated into the Korea Economic Justice Institute (KEJI) Index as a dummy variable, and analyzed the influence of CSR activities on the implied cost of capital and information asymmetry. According to the results, those companies which engaged in CSR activities more actively showed a lower implied cost of capital, and the CSR activities could relax the information asymmetry and reduce the implied cost of capital. Also, another study by Choi [26] targeted those companies which were constantly incorporated into the KEJI Index to verify the relation between CSR activities and the cost of capital, and reported that CSR activities could reduce the cost of capital.

\subsection{Hypotheses of the Study}

In this section, the hypotheses of the study were set up based on the previous studies. CSR activities allow companies to reduce the potential conflicts with various stakeholders [27] and to relax the information asymmetry by increasing their voluntary disclosure [28]. Therefore, CSR activities could reduce the cost of equity capital [14]. As usual, those companies which were incorporated into the KRX CSR Index can be classified into a category which has an excellent CSR performance. Therefore, those companies which actively engage in CSR activities are expected to lower their costs of equity capital than otherwise. Therefore, Hypothesis 1 is set up as follows:

Hypothesis 1: Those companies which are newly incorporated into the KRX SRI Index may have a lower cost of equity than those which are not.

Hypothesis 1-1: Those companies which have been incorporated into the KRX SRI Index at the time of introduction of the index may have a lower cost of equity than those which were not.

Hypothesis 1-2: Those companies which were incorporated into the KRX SRI Index at the time of revision of the index may have a lower cost of equity than those which were not.

The corporate value of a company can be defined as the sum of the present values of its future cash flow and future dividend payments which are discounted from their future values. This discount rate means the cost of equity capital, which is the proxy for the risks of the company. Therefore, the corporate value has a negative (-) relation with the cost of equity. In other words, if the cost of equity capital increases, the corporate value decreases, or if the cost of equity capital is decreased, the corporate value improves. This means an expected reduction in the cost equity due to the incorporation into the KRX SRI Index, or an increase in corporate value. Therefore, Hypothesis 2 is set up as follows:

Hypothesis 2: Those companies which are newly incorporated into the KRX SRI Index may have a higher corporate value than those which are not.

Hypothesis 2-1: Those companies which were incorporated into the KRX SRI Index at the time of introduction of the index may have a higher corporate value than those which were not.

Hypothesis 2-2: Those companies which were incorporated into the KRX SRI Index at the time of revision of the index may have a higher corporate value than those which were not. 


\section{Design of Study}

\subsection{Definition of Variables}

\subsubsection{Cost of Equity Capital}

The cost of equity capital can be estimated through a valuation model based on the hypotheses that the present stock prices should correctly reflect the intrinsic value of a company and that the expected future profits should be accurately predicted by financial analysts. In this study, the cost of equity capital was estimated by using the price-earnings growth (PEG) model developed by Easton [29] and the GM model of Gode and Mohanram [30]. The PEG model suggested by Easton [29] estimates an implied cost of equity capital based on the hypothesis that the unexpected growth rate of accounting income is ' 0 ', and the earnings per share is ' 0 ' after one quarter. The PEG model estimates an implied cost of equity by using the following Equation (1):

$$
\mathrm{R}_{\mathrm{PEG}}=\sqrt{\frac{\mathrm{FEPS}_{\mathrm{t}+2}-\mathrm{FEPS}_{\mathrm{t}+1}}{\mathrm{P}_{\mathrm{t}}}}
$$

where

$\mathrm{R}_{\mathrm{PEG}}=$ Cost of equity capital implied from the PEG model,

FEPS $_{t+1}=$ expected earnings per share of the year ' $t+1$ ' in the year ' $t$ ',

FEPS $_{t+2}=$ expected earnings per share of the year ' $t+2$ ' in the year ' $t$ ', and

$\mathrm{P}_{\mathrm{t}}=$ stock price in the year ' $\mathrm{t}$ '.

The MPEG model, which was suggested by Easton [29] as a modified version of the PEG model to consider dividends, estimates an implied cost of equity capital using the following Equation (2):

$$
\mathrm{R}_{\text {MPEG }}=\frac{\mathrm{FDPS}_{\mathrm{t}+1}+\sqrt{\mathrm{FDPS}_{\mathrm{t}+1}^{2}+2 \mathrm{P}_{\mathrm{t}}\left(\mathrm{FEPS}_{\mathrm{t}+2}-\mathrm{FEPS}_{\mathrm{t}+1}\right)}}{2 \mathrm{P}_{\mathrm{t}}}
$$

where

$\mathrm{R}_{\text {MPEG }}=$ cost of equity capital implied from the MPEG model,

FEPS $_{\mathrm{t}+1}=$ expected earnings per share of the year ' $t+1$ ' in the year ' $t$ ',

FEPS $_{\mathrm{t}+2}=$ expected earnings per share of the year ' $t+2$ ' in the year ' $t$ ', and

$P_{t}=$ stock price in the year ' $t$ '.

The GM model suggested by Gode and Mohanram [30] estimates an implied cost of equity based on the Abnormal Earnings Growth Model developed by Ohlson and Juettner-Naurot. The implied cost of equity can be estimated using the GM model as seen in the following Equation (3):

$$
\mathrm{R}_{\mathrm{GM}}=\mathrm{A}+\sqrt{\mathrm{A}^{2}+\frac{\mathrm{FEPS}_{\mathrm{t}+1}}{\mathrm{P}_{\mathrm{t}}}\left(\mathrm{g}_{2}-(\gamma-1)\right)}
$$

where

$\mathrm{A}=\frac{1}{2}(\gamma-1)+\frac{\mathrm{FDPS}_{\mathrm{t}+1}}{\mathrm{P}_{\mathrm{t}}}$

$\mathrm{g}_{2}=\frac{\mathrm{FEPS}_{\mathrm{t}+2}-\mathrm{FEPS}_{\mathrm{t}+1}}{\mathrm{P}_{\mathrm{t}}}$,

$\mathrm{g}_{\mathrm{p}}=\gamma-1=\mathrm{r}_{\mathrm{f}}-0.03$,

$\mathrm{R}_{\mathrm{GM}}=$ cost of equity capital implied from the GM model,

FEPS $_{t+1}=$ expected earnings per share of the year ' $t+1$ ' in the year ' $t$ ',

FEPS $_{t+2}=$ expected earnings per share of the year ' $t+2$ ' in the year ' $t$ ',

$\mathrm{FDPS}_{\mathrm{t}+1}=$ expected dividends of the year ' $t+1$ ' in the year ' $t$ ', 
$\mathrm{P}_{\mathrm{t}}=$ stock price in the year ' $\mathrm{t}$ ',

$\mathrm{g}_{2}=$ short-term growth rate,

$\mathrm{g}_{\mathrm{p}}=$ permanent growth rate, and

$\mathrm{r}_{\mathrm{f}}=$ risk-free interest rate.

This study applied the 3-year Treasury bond yield as the risk-free interest rate in accordance with the previous domestic studies [31,32]. Also, the study used three kinds of implied costs of equity and the average of three models.

\subsubsection{Corporate Value}

Corporate value was estimated using Tobin's $Q$ ratio, which has been the most frequently used by the previous studies [10,33-35]. Tobin's Q suggested by Chung and Pruitt [36] was used as the proxy for the market value performance index and is presented in Equation (4):

$$
\text { Tobin's } Q=\frac{(\mathrm{MV}+\mathrm{BVP})+\mathrm{BVD}}{\mathrm{BVT}}
$$

where

$\mathrm{MV}=$ market value of common stocks,

$\mathrm{BVP}=$ book value of preferred stocks,

$\mathrm{BVD}=$ book value of debts, and

$\mathrm{BVT}=$ book value of total assets.

\subsubsection{Social Responsibility}

The CSR performance was determined depending on whether companies were incorporated or not into the KRX SRI Index (The alternative CSR indexes included not only the KRX SRI index but also the KEJI index, DJSI Korea (Dow Jones Sustainability Index Korea), etc.). The KRX SRI Index is an index which is designed to improve domestic companies' awareness about socially responsible investment security markets and sustainable management, and which consists of 70 outstanding SRI companies listed on the Security market and the Korean Securities Dealers Automated Quotations (KOSDAQ) market. The selection procedure of the SRI Index was implemented by targeting only those with an ESG-integrated rating of B+ or above among the stocks listed on the Security market and the KOSDAQ market and by shortening the list to only those which satisfy the minimum screening requirements in terms of market capitalization, trading volume and liquidity ratio, based on data on the ESG integrated ratings evaluated by the Korea Corporate Governance Service. (The content relating to the KRX SRI index was described in reference to the official website of the Korea Exchange (www.krx.co.kr).) The evaluation of the component stocks of the KRX SRI Index are regularly evaluated on the next day following the last trading day of the contract month of September of the KOSPI 200 futures market. And whenever a legitimate cause for special revision occurs, a change to the list of the component stocks will take place.

This study classified those which were incorporated into the KRX SRI index as a group of companies with an outstanding CSR activity performance and analyzed how a company's cost of equity capital and corporate value were influenced by whether or not it is incorporated into the KRX SRI index. To verify this, this study conducted an analysis to identify differences between before and after the incorporation into the KRX SRI index, and selected those companies similar to the incorporated companies as a control group in order to compare the control company group with the incorporated company group. For this analysis, the SRI dummy variable was used. (The control group was selected based on the total assets and the Korean Standard Industrial Classification Code (medium classification level)) For the latitudinal analysis, the previous year before incorporation into the KRX SRI index was set as ' 0 ', while the year of incorporation into the KRX SRI index was set as ' 1 '. For the 
longitudinal analysis, those incorporated into the KRX SRI index were set as ' 1 ', while those which were not incorporated were set as ' 0 '.

\subsection{Study Model}

The study analyzed the relation between cost of equity and corporate value due to incorporation into the KRX SRI index. To verify the effect of the socially responsible investment index, this study set up the following Equations (5) and (6):

$$
\begin{gathered}
\text { COC }=\alpha_{0}+\alpha_{1} \text { SRIdummy }+\alpha_{2} \mathrm{BM}+\alpha_{3} \mathrm{LEV}+\alpha_{4} \mathrm{SIZE}+\alpha_{5} \mathrm{BETA}+\alpha_{6} \mathrm{BIG}+\alpha_{7} \mathrm{FOR}+\varepsilon \\
\text { TobinQ }=\alpha_{0}+\alpha_{1} \mathrm{SRI} d u m m y+\alpha_{2} \mathrm{BM}+\alpha_{3} \mathrm{LEV}+\alpha_{4} \mathrm{SIZE}+\alpha_{5} \mathrm{BETA}+\alpha_{6} \mathrm{BIG}+\alpha_{7} \mathrm{FOR}+\varepsilon
\end{gathered}
$$

where

COC $=$ Implied cost of equity using PEG Model, MPEG Model, and GM Model,

TobinQ $=$ Tobin's $Q$,

SRIdummy = The dummy variable is ' 0 ' before incorporation into the KRX SRI index, whereas the dummy variable is ' 1 ' in the year of incorporation,

SRIdummy_Control = The dummy variable is ' 1 ' if a company is incorporated into the KRX SRI index, whereas the dummy variable is ' 0 ' if it belongs to the control group,

$\mathrm{BM}=$ ratio of book value to market value,

$\mathrm{LEV}=$ debt ratio,

SIZE = company size,

BETA $=$ market beta,

BIG = large shareholders' equity holding rate, and

$\mathrm{FOR}=$ foreigner equity ratio.

Equation (5) was a pooled OLS model to verify changes in the cost of equity due to incorporation into the KRX SRI index. By classifying those incorporated into the KRX SRI index as a group of companies with an outstanding CSR activity performance, the relation between the CSR and the cost of equity was analyzed. For the verification of the model, the dummy variable for the year before the incorporation into the KRX SRI index was set as ' 0 ' whereas the dummy variable for the year of incorporation was set as ' 1 '. Since a company with an outstanding CSR activity performance is expected to have a lower cost of equity, the SRIdummy variable coefficient ' $\alpha_{0}$ ' is predicted to have a negative $(-)$ value.

Equation (6) is a pooled OLS model to verify how the incorporation into the KRX SRI index affects the corporate value. For the verification of the model, the dummy variable for the year before the incorporation into the KRX SRI index is set as ' 0 ' whereas the dummy variable for the year of incorporation is set as ' 1 '. Since a company with an outstanding CSR activity performance is expected to have a higher corporate value, the SRIdummy variable coefficient is predicted to have a positive $(+)$ value.

Also, for the latitudinal analysis, the dummy variable for the incorporated company group was set as ' 1 ' whereas the dummy variable for the control group was set as ' 0 ' in order to verify the cost of equity at the time of incorporation into the KRX SRI index. Since a company incorporated into the KRX SRI index is expected to have a lower cost of equity capital, the SRIdummy_Control variable coefficient is predicted to have a negative $(-)$ value.

In accordance with the previous studies, the book value to market value ratio, debt ratio, company size, market beta, large shareholders' equity holding ratio, and foreigner equity ratio were used as controlled variables which have influence on the cost of equity capital of a company. As a company's cost of equity is closely connected with its risks, the book value to market value ratio, debt ratio, company size, and market beta were used. A study by Fama and French [37] reported that in addition 
to the market beta and company size, the book value to market value ratio also includes the inherent risks of a company. Therefore, the book value to market value (BM) ratio is expected to have a positive relation with the cost of equity capital, and the market beta (BETA) is also predicted to have a positive $(+)$ relation with the cost of equity capital. Another study by Botosan and Plumlee [38] reported that if a company has a larger size, the information asymmetry can be reduced. Given this, the company size is expected to have a negative (-) relation with the cost of equity capital. Another study by Francis et al. [39] reported that if the debt ratio increases, investors feel greater risks. In consideration of this, the debt ratio (LEV) is expected to have a positive (+) relation with the cost of equity capital. Also, the previous studies said that although such corporate governance variables as the equity holding ratio of large shareholders and the foreigner equity ratio may have inconsistent directions, both have an influence on the cost of equity capital of a company. Therefore, the corporate governance variables, such as the equity holding ratio of large shareholders and the foreigner equity, were included in the model.

\subsection{Sampling of Study Subjects}

Among those companies which are incorporated into the KRX SRI index, only the companies that met the following requirements were selected as the sample companies for this study:

1. Companies whose closing date is on 31 December,

2. Companies which do not belong to the finance industry,

3. Companies whose capital is not impaired,

4. Companies whose financial data is available, and

5. Companies which keep financial analysts' earnings forecasts from 2009 to 2013.

The analysis period of this study ranged from 2009, when the KRX SRI index was introduced, to 2013. In the selection of the analysis subjects, Condition 1. is to secure the homogeneity of samples. In case of Condition 2, since the financial statements of the finance industry have different characteristics from a manufacturing company, it is difficult to compare them with those of other industries. In case of Condition 3, since a company whose capital is impaired has a distorted financial ratio, the analysts' earnings forecasts can be biased. In case of Condition 4 , it was to secure the data necessary for the model of the study. In case of Condition 5, it was to estimate the cost of equity capital. The financial analysts' earnings forecasts and the financial statements necessary for the study were collected from Fn-Guide. Ultimately, 86 companies that met all the above conditions were selected as the final study subjects.

\section{Empirical Analysis}

\subsection{Descriptive Statistics}

The major variables in Table 1 indicate descriptive statistics. The median cost of equity capital used for this study was the average of implied cost of equity estimated by the PEG (0.144[0.123]), MPEG (0.155[0.131]), and GM (0.156[0.132]) models. The average implied cost of equity capital was estimated at 0.152(0.129). In other words, the sample companies must pay the cost of equity capital of $15.2 \%$ in the Korean stock market.

Table 2 shows Pearson's correlations between major variables. The implied costs of equity such as $\mathrm{COC}_{\mathrm{AVG}}, \mathrm{COC}_{\mathrm{PEG}}, \mathrm{COC}_{\mathrm{MPEG}}$ and $\mathrm{COC}_{\mathrm{GM}}$ had a negative relation (-) with SRIdummy, the proxy variable for CSR activities. This means that if a company is incorporated into the KRX SRI index, its cost of equity capital will be lowered. The result can be interpreted as supporting Hypothesis 1 of this study. They had a positive (+) relation with explanatory variables such as the book value to market value (BM) ratio, debt ratio (LEV), company size (SIZE), and market beta (BETA), whereas they had a negative (-) relation with the equity holding ratio of large shareholders (BIG) and the foreigner equity ratio (FOR). In other words, if the book value to market value (BM) ratio, debt ratio (LEV), 
company size (SIZE), and market beta (BETA) are increased, a company's cost of equity will go up, whereas the cost of equity will be lowered if the equity-holding ratio of large shareholders and the foreigner equity ratio are increased.

Table 1. Descriptive Statistics of Independent and Dependent Variables for Regression Analysis

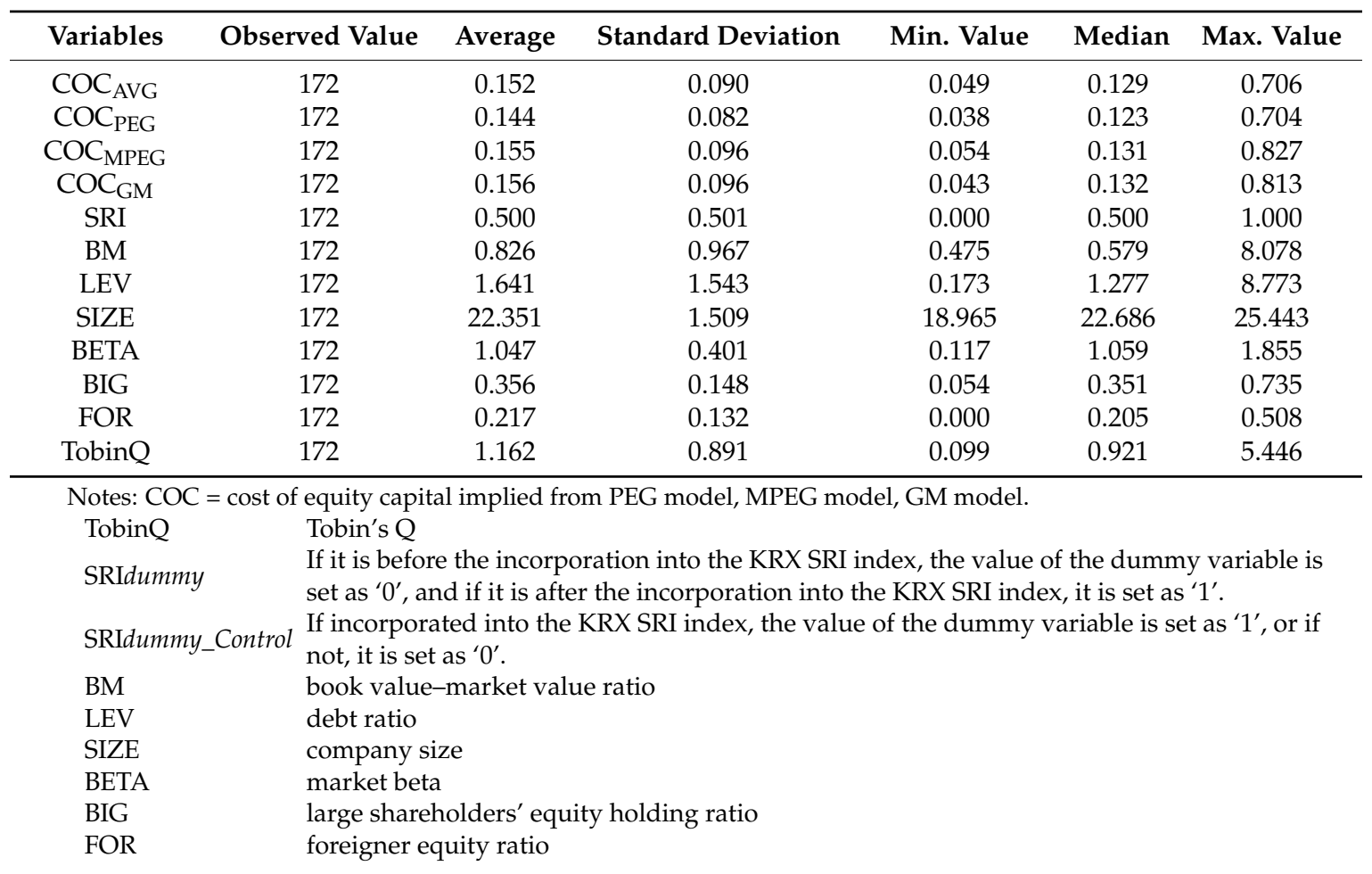

\subsection{Regression Analysis}

Table 3 shows the results of regression analysis to verify Hypothesis 1 . The entire sample companies were targeted for analysis to identify the relation between the incorporation into the KRX SRI Index and the cost of equity capital for them. (Since the model's variance inflation factor (VIF) values are all below 2, it is believed that there were no problems with multi-collinearity.) According to the analysis results, the values of 'SRIdummy', the coefficient for the incorporation into the KRX SRI Index, did not have any significant relation with the implied costs of equity capital $\mathrm{COC}_{\mathrm{AVG}}, \mathrm{COC}_{\mathrm{PEG}}$, $\mathrm{COC}_{\mathrm{MPEG}}$, and $\mathrm{COC}_{\mathrm{GM}}$. In other words, it means that the incorporation into the KRX SRI Index did not have an influence on the cost of equity capital. The results can be interpreted as follows. First, either Korean investors may not think that companies' CSR activities contribute to enhancing corporate value, or this can be the result of a mixed presence of optimists and pessimists about CSR activities. Secondly, it can be interpreted as the fact that the KRX SRI index might not correctly reflect companies' CSR activities. This can be ascribed to the fact that as the KRX SRI index is a market-weighted index, it consists mainly of large companies which are ranked high in terms of the aggregate value of listed stocks, which makes it difficult to accurately reflect companies' CSR activities.

Among the risk factors used as explanatory variables, the book value to market value ratio, debt ratio, and large shareholders' equity-holding ratio showed a significant relationship. The book value to market value (BM) ratio and the debt ratio (LEV) had a significant positive $(+)$ relation of $5 \%$ and $1 \%$, respectively, with the cost of equity capital. This means that if the BM ratio or the debt ratio is increased, the cost of equity capital is getting higher. The large shareholders' equity-holding ratio, which was a variable for corporate governance structure, had a significant negative (-) relation of $10 \%$ with the cost of equity capital. It means that if large shareholders' equity-holding ratio is increased, the cost of equity capital is getting lower. 
Table 2. Correlation Coefficients between Major Regression Model Variables.

\begin{tabular}{|c|c|c|c|c|c|c|c|c|c|c|c|c|}
\hline Variables & $\mathrm{COC}_{\mathrm{AVG}}$ & $\mathrm{COC}_{\mathrm{PEG}}$ & $\mathrm{COC}_{\text {MPEG }}$ & $\mathrm{COC}_{\mathrm{GM}}$ & SRI & $\mathbf{B M}$ & LEV & SIZE & BETA & BIG & FOR & TobinQ \\
\hline $\mathrm{COC}_{\mathrm{AVG}}$ & 1.000 & & & & & & & & & & & \\
\hline $\mathrm{COC}_{\mathrm{PEG}}$ & $\begin{array}{l}0.954^{* * *} \\
(<0.001)\end{array}$ & 1.000 & & & & & & & & & & \\
\hline $\mathrm{COC}_{\mathrm{MPEG}}$ & $\begin{array}{l}0.992 * * * \\
(<0.001)\end{array}$ & $\begin{array}{l}0.908^{* * *} \\
(<0.001)\end{array}$ & 1.000 & & & & & & & & & \\
\hline $\mathrm{COC}_{\mathrm{GM}}$ & $\begin{array}{l}0.992 * * * \\
(<0.001)\end{array}$ & $\begin{array}{l}0.906^{* * *} \\
(<0.001)\end{array}$ & $\begin{array}{l}0.999 * * * \\
(<0.001)\end{array}$ & 1.000 & & & & & & & & \\
\hline SRI & $\begin{array}{l}-0.058 \\
(0.453) \\
\end{array}$ & $\begin{array}{l}-0.082 \\
(0.288) \\
\end{array}$ & $\begin{array}{l}-0.046 \\
(0.552)\end{array}$ & $\begin{array}{c}-0.046 \\
(0.550)\end{array}$ & 1.000 & & & & & & & \\
\hline $\mathrm{BM}$ & $\begin{array}{l}0.188 * * \\
(0.014)\end{array}$ & $\begin{array}{c}0.207^{* * * *} \\
(0.006)\end{array}$ & $\begin{array}{l}0.174^{* *} \\
(0.022)\end{array}$ & $\begin{array}{l}0.175 * * \\
(0.022)\end{array}$ & $\begin{array}{l}-0.018 \\
(0.816) \\
\end{array}$ & 1.000 & & & & & & \\
\hline LEV & $\begin{array}{l}0.362^{* * *} \\
(<0.001)\end{array}$ & $\begin{array}{l}0.383^{* * *} \\
(<0.001)\end{array}$ & $\begin{array}{l}0.343^{* * *} \\
(<0.001)\end{array}$ & $\begin{array}{l}0.343^{* * *} \\
(<0.001)\end{array}$ & $\begin{array}{l}-0.017 \\
(0.827)\end{array}$ & $\begin{array}{c}0.114 \\
(0.138) \\
\end{array}$ & 1.000 & & & & & \\
\hline SIZE & $\begin{array}{c}0.085 \\
(0.266)\end{array}$ & $\begin{array}{c}0.101 \\
(0.186)\end{array}$ & $\begin{array}{c}0.076 \\
(0.320)\end{array}$ & $\begin{array}{c}0.076 \\
(0.323)\end{array}$ & $\begin{array}{c}0.024 \\
(0.753)\end{array}$ & $\begin{array}{l}0.436^{* * *} \\
(<0.001)\end{array}$ & $\begin{array}{l}0.309 * * * \\
(<0.001)\end{array}$ & 1.000 & & & & \\
\hline BETA & $\begin{array}{c}0.160 \text { ** } \\
(0.036)\end{array}$ & $\begin{array}{c}0.213^{* * * *} \\
(0.005)\end{array}$ & $\begin{array}{l}0.131 \text { * } \\
(0.086)\end{array}$ & $\begin{array}{l}0.134^{*} \\
(0.080)\end{array}$ & $\begin{array}{l}-0.002 \\
(0.984)\end{array}$ & $\begin{array}{c}0.225^{* * *} \\
(0.003)\end{array}$ & $\begin{array}{l}0.364^{* * *} \\
(<0.001)\end{array}$ & $\begin{array}{l}0.276^{* * *} \\
(<0.001)\end{array}$ & 1.000 & & & \\
\hline BIG & $\begin{array}{l}-0.073 \\
(0.341) \\
\end{array}$ & $\begin{array}{l}-0.046 \\
(0.550)\end{array}$ & $\begin{array}{l}-0.083 \\
(0.281) \\
\end{array}$ & $\begin{array}{l}-0.083 \\
(0.282)\end{array}$ & $\begin{array}{l}-0.015 \\
(0.849)\end{array}$ & $\begin{array}{c}0.028 \\
(0.712)\end{array}$ & $\begin{array}{c}0.091 \\
(0.238)\end{array}$ & $\begin{array}{c}-0.134 * \\
(0.079)\end{array}$ & $\begin{array}{c}0.116 \\
(0.128)\end{array}$ & 1.000 & & \\
\hline FOR & $\begin{array}{l}-0.124 \\
(0.106)\end{array}$ & $\begin{array}{c}-0.193 \text { ** } \\
(0.011)\end{array}$ & $\begin{array}{l}-0.091 \\
(0.234)\end{array}$ & $\begin{array}{l}-0.091 \\
(0.236)\end{array}$ & $\begin{array}{c}0.105 \\
(0.172)\end{array}$ & $\begin{array}{l}-0.052 \\
(0.503)\end{array}$ & $\begin{array}{c}-0.269 * * * \\
(<0.001)\end{array}$ & $\begin{array}{l}0.306^{* * *} \\
(<0.001)\end{array}$ & $\begin{array}{c}-0.299 * * * \\
(<0.001)\end{array}$ & $\begin{array}{c}-0.427^{* * *} \\
(<0.001)\end{array}$ & 1.000 & \\
\hline TobinQ & $\begin{array}{c}-0.167^{* *} \\
(0.028)\end{array}$ & $\begin{array}{c}-0.177^{* *} \\
(0.020)\end{array}$ & $\begin{array}{c}-0.158^{* *} \\
(0.039)\end{array}$ & $\begin{array}{c}-0.160^{* *} \\
(0.037)\end{array}$ & $\begin{array}{c}0.064 \\
(0.407)\end{array}$ & $\begin{array}{c}-0.523 \text { *** } \\
(<0.001)\end{array}$ & $\begin{array}{c}-0.217^{* * *} \\
(0.004)\end{array}$ & $\begin{array}{c}-0.485^{* * *} \\
(<0.001)\end{array}$ & $\begin{array}{c}-0.222 \text { *** } \\
(0.003)\end{array}$ & $\begin{array}{l}-0.114 \\
(0.137)\end{array}$ & $\begin{array}{l}0.176^{* *} \\
(0.021)\end{array}$ & 1.000 \\
\hline
\end{tabular}

Notes: This table reports Pearson's correlation coefficients. Numbers in parentheses are $p$-values for correlation coefficients. The definition of variables can be referred to in Table $1 .{ }^{* * *}, * *, *$ respectively indicate a significance level of $1 \%, 5 \%$ or $10 \%$ 
Table 3. Results of Regression Analysis to Verify Hypothesis $1 .^{1}$

\begin{tabular}{|c|c|c|c|c|c|c|c|c|c|}
\hline \multirow[b]{2}{*}{ Variables } & \multirow{2}{*}{$\begin{array}{l}\text { Pred. } \\
\text { Sign }\end{array}$} & \multicolumn{2}{|c|}{$\mathrm{COC}_{\mathrm{AVG}}$} & \multicolumn{2}{|c|}{$\mathrm{COC}_{\mathrm{PEG}}$} & \multicolumn{2}{|c|}{$\mathrm{COC}_{\text {MPEG }}$} & \multicolumn{2}{|c|}{$\mathrm{COC}_{\mathrm{GM}}$} \\
\hline & & Coef. & $\begin{array}{c}t \text {-Stat. } \\
(p \text {-Value) }\end{array}$ & Coef. & $\begin{array}{c}t \text {-Stat. } \\
(p \text {-Value) }\end{array}$ & Coef. & $\begin{array}{c}t \text {-Stat. } \\
(p \text {-Value })\end{array}$ & Coef. & $\begin{array}{c}t \text {-Stat. } \\
\text { ( } p \text {-Value) }\end{array}$ \\
\hline Intercept & & $0.305^{* * *}$ & $\begin{array}{c}2.68 \\
(0.008) \\
\end{array}$ & $0.241^{* *}$ & $\begin{array}{c}2.35 \\
(0.020) \\
\end{array}$ & $0.335^{* *}$ & $\begin{array}{c}2.72 \\
(0.007)\end{array}$ & $0.338^{* * *}$ & $\begin{array}{c}2.74 \\
(0.007) \\
\end{array}$ \\
\hline SRIdummy & - & -0.008 & $\begin{array}{l}-0.63 \\
(0.532)\end{array}$ & -0.010 & $\begin{array}{c}-0.88 \\
(0.379)\end{array}$ & -0.007 & $\begin{array}{l}-0.50 \\
(0.619)\end{array}$ & -0.007 & $\begin{array}{l}-0.50 \\
(0.615)\end{array}$ \\
\hline $\mathrm{BM}$ & + & $0.034^{* *}$ & $\begin{array}{c}2.50 \\
(0.013) \\
\end{array}$ & $0.030 * *$ & $\begin{array}{c}2.44 \\
(0.016) \\
\end{array}$ & $0.036^{* *}$ & $\begin{array}{c}2.44 \\
(0.016) \\
\end{array}$ & $0.036^{* *}$ & $\begin{array}{c}2.45 \\
(0.015) \\
\end{array}$ \\
\hline LEV & + & $0.022^{* * *}$ & $\begin{array}{c}4.60 \\
(<0.001)\end{array}$ & $0.019 * * *$ & $\begin{array}{c}4.39 \\
(<0.001)\end{array}$ & $0.024^{* * *}$ & $\begin{array}{c}4.54 \\
(<0.001)\end{array}$ & $0.024^{* * *}$ & $\begin{array}{c}4.55 \\
(<0.001)\end{array}$ \\
\hline SIZE & - & -0.008 & $\begin{array}{l}-1.46 \\
(0.146)\end{array}$ & -0.005 & $\begin{array}{l}-1.03 \\
(0.306)\end{array}$ & -0.010 & $\begin{array}{c}-1.58 \\
(0.116)\end{array}$ & -0.010 & $\begin{array}{l}-1.61 \\
(0.110)\end{array}$ \\
\hline BETA & + & 0.005 & $\begin{array}{c}0.32 \\
(0.752)\end{array}$ & 0.011 & $\begin{array}{c}0.67 \\
(0.504)\end{array}$ & 0.003 & $\begin{array}{c}0.14 \\
(0.891)\end{array}$ & 0.004 & $\begin{array}{c}0.18 \\
(0.857)\end{array}$ \\
\hline BIG & $?$ & $-0.087^{*}$ & $\begin{array}{c}-1.83 \\
(0.069)\end{array}$ & -0.080 * & $\begin{array}{l}-1.89 \\
(0.061)\end{array}$ & -0.090 * & $\begin{array}{l}-1.75 \\
(0.081)\end{array}$ & -0.090 * & $\begin{array}{l}-1.75 \\
(0.083)\end{array}$ \\
\hline FOR & $?$ & -0.011 & $\begin{array}{l}-0.17 \\
(0.864)\end{array}$ & -0.059 & $\begin{array}{c}-1.02 \\
(0.309)\end{array}$ & 0.012 & $\begin{array}{c}0.17 \\
(0.865)\end{array}$ & 0.014 & $\begin{array}{c}0.20 \\
(0.840)\end{array}$ \\
\hline \multicolumn{2}{|c|}{ Obs (n) } & \multicolumn{2}{|c|}{172} & \multicolumn{2}{|c|}{172} & \multicolumn{2}{|c|}{172} & \multicolumn{2}{|c|}{172} \\
\hline \multicolumn{2}{|c|}{ Firms (n) } & \multicolumn{2}{|c|}{86} & \multicolumn{2}{|c|}{86} & \multicolumn{2}{|c|}{86} & \multicolumn{2}{|c|}{86} \\
\hline \multicolumn{2}{|c|}{ F-value } & \multicolumn{2}{|c|}{$5.26^{* * *}$} & \multicolumn{2}{|c|}{$6.19^{* * *}$} & \multicolumn{2}{|c|}{$4.68^{* * *}$} & \multicolumn{2}{|c|}{$4.70^{* * *}$} \\
\hline \multicolumn{2}{|c|}{ Adj R2 } & \multicolumn{2}{|c|}{$14.84 \%$} & \multicolumn{2}{|c|}{$17.53 \%$} & \multicolumn{2}{|c|}{$16.64 \%$} & \multicolumn{2}{|c|}{$13.46 \%$} \\
\hline
\end{tabular}

Notes: The definition of variables can be referred to in Table $1 . * * * * * *$ respectively indicate a significance level of $1 \%, 5 \%$ or $10 \% ;{ }^{1} \mathrm{COC}=\alpha_{0}+\alpha_{1} \mathrm{SRI} d u m m y+\alpha_{2} \mathrm{BM}+\alpha_{3} \mathrm{LEV}+\alpha_{4} \mathrm{SIZE}+\alpha_{5} \mathrm{BETA}+\alpha_{6} \mathrm{BIG}+\alpha_{7} \mathrm{FOR}+\varepsilon$

Table 4 shows the result of regression analysis to verify Hypothesis 1-1. Those companies which were incorporated at the time of the introduction of the KRX SRI index were targeted for analysis to identify the relation between the incorporation into the KRX SRI Index and the cost of equity capital by using Equation (5). (Since the model's variance inflation factor (VIF) values are all below 2, it is believed that there were no problems with multi-collinearity.) According to the analysis results, the values of 'SRIdummy', the coefficient for the incorporation into the KRX SRI Index, had a significant negative (-) relation of $5 \%$ with $\mathrm{COC}_{\mathrm{PEG}}$, the implied cost of equity capital. In other words, it means that the incorporation into the KRX SRI Index at the time of its introduction resulted in a reduction in the cost of equity capital. Thus, the cost of equity capital after the incorporation into the KRX SRI Index was lowered after the incorporation into the KRX SRI Index. It means that there were many optimistic investors about the incorporation into the KRX SRI Index at the time of its introduction, and this can be interpreted as the fact that CSR activities play a role in reducing the cost of equity capital.

Among the risk factors used as explanatory variables, the BM ratio, large shareholders' equity-holding ratio, and foreigner equity ratio showed a significant relationship. The debt ratio (LEV) had a significant positive (+) relation of $1 \%$, with all the implied costs of equity capital. This means that if the debt ratio is increased, the cost of equity capital is getting higher. The large shareholders' equity holding ratio and the foreigner equity ratio, which were variables for corporate governance structure, showed different relations depending on models. The large shareholders' equity holding ratio had a significant negative (-) relation of $10 \%$ when $\mathrm{COC}_{\mathrm{MPEG}}$ and $\mathrm{COC}_{\mathrm{GM}}$, the implied costs of equity capital estimated using MPEG and GM models, were used as independent variables. It means that if large shareholders' equity holding ratio is increased, the cost of equity capital is getting lower. The foreigner equity ratio had a significant negative (-) relation of $5 \%$ with the cost of equity capital when $\mathrm{COC}_{\mathrm{AVG}}$ and $\mathrm{COC}_{\mathrm{PEG}}$, the implied costs of equity capital estimated using PEG model, were used as independent variables. It means that if the foreigner equity ratio is increased, the cost of equity capital is getting lower. This result is consistent with the previous studies which reported that the governance structure had influence on the cost of equity capital $[15,25,40,41]$. 
Table 4. Results of Regression Analysis to Verify Hypothesis 1-1. ${ }^{1}$

\begin{tabular}{|c|c|c|c|c|c|c|c|c|c|}
\hline \multirow[b]{2}{*}{ Variables } & \multirow{2}{*}{$\begin{array}{l}\text { Pred. } \\
\text { Sign }\end{array}$} & \multicolumn{2}{|c|}{$\mathrm{COC}_{\mathrm{AVG}}$} & \multicolumn{2}{|c|}{$\mathrm{COC}_{\mathrm{PEG}}$} & \multicolumn{2}{|c|}{$\mathrm{COC}_{\text {MPEG }}$} & \multicolumn{2}{|c|}{$\mathrm{COC}_{\mathrm{GM}}$} \\
\hline & & Coef. & $\begin{array}{c}t \text {-Stat. } \\
(p \text {-Value) }\end{array}$ & Coef. & $\begin{array}{c}t \text {-Stat. } \\
(p \text {-Value) }\end{array}$ & Coef. & $\begin{array}{c}t \text {-Stat. } \\
(p \text {-Value) }\end{array}$ & Coef. & $\begin{array}{c}t \text {-Stat. } \\
(p \text {-Value })\end{array}$ \\
\hline Intercept & & $0.288^{* *}$ & $\begin{array}{c}1.83 \\
(0.071) \\
\end{array}$ & 0.212 & $\begin{array}{c}1.53 \\
(0.128) \\
\end{array}$ & $0.325^{*}$ & $\begin{array}{c}1.87 \\
(0.064) \\
\end{array}$ & $0.326^{*}$ & $\begin{array}{c}1.88 \\
(0.063) \\
\end{array}$ \\
\hline SRIdummy & - & -0.031 & $\begin{array}{c}-1.64 \\
(0.105)\end{array}$ & $-0.035^{* *}$ & $\begin{array}{c}-2.11 \\
(0.038)\end{array}$ & -0.29 & $\begin{array}{c}-1.39 \\
(0.168)\end{array}$ & -0.029 & $\begin{array}{l}-1.39 \\
(0.167)\end{array}$ \\
\hline $\mathrm{BM}$ & + & 0.029 & $\begin{array}{c}1.50 \\
(0.137)\end{array}$ & 0.023 & $\begin{array}{c}1.38 \\
(0.172)\end{array}$ & 0.031 & $\begin{array}{c}1.48 \\
(0.141)\end{array}$ & 0.032 & $\begin{array}{c}1.50 \\
(0.136)\end{array}$ \\
\hline LEV & + & $0.026^{* * *}$ & $\begin{array}{c}4.01 \\
(<0.001)\end{array}$ & $0.022 * * *$ & $\begin{array}{c}3.83 \\
(<0.001)\end{array}$ & $0.028^{* * *}$ & $\begin{array}{c}3.93 \\
(<0.001)\end{array}$ & $0.028 * * *$ & $\begin{array}{c}3.93 \\
(<0.001)\end{array}$ \\
\hline SIZE & - & -0.005 & $\begin{array}{l}-0.68 \\
(0.499)\end{array}$ & -0.002 & $\begin{array}{l}-0.27 \\
(0.785)\end{array}$ & -0.007 & $\begin{array}{l}-0.80 \\
(0.423)\end{array}$ & -0.007 & $\begin{array}{c}-0.83 \\
(0.411)\end{array}$ \\
\hline BETA & + & -0.021 & $\begin{array}{l}-0.77 \\
(0.443)\end{array}$ & -0.011 & $\begin{array}{l}-0.46 \\
(0.649)\end{array}$ & -0.027 & $\begin{array}{l}-0.88 \\
(0.380)\end{array}$ & -0.026 & $\begin{array}{l}-0.85 \\
(0.397)\end{array}$ \\
\hline BIG & $?$ & -0.002 & $\begin{array}{c}-0.02 \\
(0.984)\end{array}$ & -0.055 & $\begin{array}{c}-0.71 \\
(0.482)\end{array}$ & $-0.156^{*}$ & $\begin{array}{c}-1.92 \\
(0.058)\end{array}$ & $-0.156^{*}$ & $\begin{array}{c}-1.92 \\
(0.058)\end{array}$ \\
\hline FOR & $?$ & $-0.149^{* *}$ & $\begin{array}{l}-2.02 \\
(0.046)\end{array}$ & $-0.134 * *$ & $\begin{array}{l}-2.08 \\
(0.040)\end{array}$ & 0.023 & $\begin{array}{c}0.24 \\
(0.814)\end{array}$ & 0.026 & $\begin{array}{c}0.27 \\
(0.063)\end{array}$ \\
\hline \multicolumn{2}{|c|}{ Obs (n) } & \multicolumn{2}{|c|}{106} & \multicolumn{2}{|c|}{106} & \multicolumn{2}{|c|}{106} & \multicolumn{2}{|c|}{106} \\
\hline \multicolumn{2}{|c|}{ Firms (n) } & \multicolumn{2}{|c|}{53} & \multicolumn{2}{|c|}{53} & \multicolumn{2}{|c|}{53} & \multicolumn{2}{|c|}{53} \\
\hline \multicolumn{2}{|c|}{ F-value } & \multicolumn{2}{|c|}{$3.70^{* * *}$} & \multicolumn{2}{|c|}{$4.62^{* * *}$} & \multicolumn{2}{|c|}{$3.19^{* * *}$} & \multicolumn{2}{|c|}{$3.20^{* * *}$} \\
\hline \multicolumn{2}{|c|}{ Adj R2 } & \multicolumn{2}{|c|}{$15.25 \%$} & \multicolumn{2}{|c|}{$19.44 \%$} & \multicolumn{2}{|c|}{$12.73 \%$} & \multicolumn{2}{|c|}{$12.79 \%$} \\
\hline
\end{tabular}

Notes: The definition of variables can be referred to in Table $1 ; * * * * * *$ respectively indicate a significance level of $1 \%, 5 \%$ or $10 \% ;{ }^{1}$ COC $=\alpha_{0}+\alpha_{1}$ SRIdummy $+\alpha_{2}$ BM $+\alpha_{3}$ LEV $+\alpha_{4}$ SIZE $+\alpha_{5}$ BETA $+\alpha_{6}$ BIG $+\alpha_{7}$ FOR $+\varepsilon$.

Table 5 shows the results of regression analysis to verify Hypothesis 1-2. Those companies which were incorporated at the time of the change of the KRX SRI index were targeted for analysis to identify the relation between the incorporation into the KRX SRI Index and the cost of equity capital by using Equation (5). (Since the model's variance inflation factor (VIF) values are all below 2, it is believed that there were no problems with multi-collinearity.) According to the analysis results, the values of 'SRIdummy', the coefficient for the incorporation into the KRX SRI Index, had a significant positive (+) relation of $10 \%$ with $\mathrm{COC}_{\mathrm{AVG}}, \mathrm{COC}_{\mathrm{PEG}}$ and $\mathrm{COC}_{\mathrm{MPEG}}$, except for $\mathrm{COC}_{\mathrm{GM}}$, the implied cost of equity capital. This is the opposite result against the above-mentioned result that the incorporation into the KRX SRI Index at the time of its introduction resulted in a reduction in the cost of equity capital. In other words, companies which were incorporated at the time of introduction could reduce the cost of equity capital, whereas those which were incorporated at the time of change of the index experienced an increase in their costs of equity capital. It means that more and more investors became pessimistic about CSR activities over the course of time. The reason for the opposing results between times of introduction and change of the index is that, as the index was made up mainly of large companies at the time of introduction, there were many investors who were optimistic about CSR activities, but as the index included many relatively smaller-sized companies after the change of the index, there were more people who were pessimistic about CSR activities.

Among the risk factors used as explanatory variables, the BM ratio, debt ratio, and market beta showed a statistically significant relationship. The BM ratio and the debt (LEV) ratio had a statistically significant positive (+) relation of $1 \%$ with the cost of equity capital. As seen above, this can be interpreted as the fact that if the BM ratio or the debt ratio is increased, the cost of equity capital is getting higher. Also, the market beta (BETA) had a significant positive $(+)$ relation of $10 \%$ with $\mathrm{COC}_{\mathrm{AVG}}, \mathrm{COC}_{\mathrm{MPEG}}$ and $\mathrm{COC}_{\mathrm{GM}}$, the implied costs of equity capital. It means that a higher market beta results in an increase in the cost of equity capital. Because the index included a larger number of relatively smaller-sized companies at the time of change of component stocks, it became more influenced by the market beta than it was at the time of introduction. 
Table 5. Results of Regression Analysis to Verify Hypothesis 1-2. ${ }^{1}$

\begin{tabular}{|c|c|c|c|c|c|c|c|c|c|}
\hline \multirow[b]{2}{*}{ Variables } & \multirow{2}{*}{$\begin{array}{l}\text { Pred. } \\
\text { Sign }\end{array}$} & \multicolumn{2}{|c|}{$\mathrm{COC}_{\mathrm{AVG}}$} & \multicolumn{2}{|c|}{$\mathrm{COC}_{\mathrm{PEG}}$} & \multicolumn{2}{|c|}{$\mathrm{COC}_{\text {MPEG }}$} & \multicolumn{2}{|c|}{$\mathrm{COC}_{\mathrm{GM}}$} \\
\hline & & Coef. & $\begin{array}{c}t \text {-Stat. } \\
(p \text {-Value) }\end{array}$ & Coef. & $\begin{array}{c}t \text {-Stat. } \\
(p \text {-Value) }\end{array}$ & Coef. & $\begin{array}{c}t \text {-Stat. } \\
(p \text {-Value) }\end{array}$ & Coef. & $\begin{array}{c}t \text {-Stat. } \\
(p \text {-Value })\end{array}$ \\
\hline Intercept & & 0.192 & $\begin{array}{c}1.40 \\
(0.168)\end{array}$ & 0.195 & $\begin{array}{c}1.44 \\
(0.548)\end{array}$ & 0.189 & $\begin{array}{c}1.36 \\
(0.178)\end{array}$ & 0.193 & $\begin{array}{c}1.38 \\
(0.173)\end{array}$ \\
\hline SRIdummy & - & 0.022 * & $\begin{array}{c}1.71 \\
(0.093)\end{array}$ & $0.022 *$ & $\begin{array}{c}1.78 \\
(0.081)\end{array}$ & $0.022 *$ & $\begin{array}{c}1.69 \\
(0.097) \\
\end{array}$ & 0.022 & $\begin{array}{c}1.66 \\
(0.102)\end{array}$ \\
\hline $\mathrm{BM}$ & + & $0.083^{* * *}$ & $\begin{array}{c}4.24 \\
(<0.001)\end{array}$ & $0.082^{* * *}$ & $\begin{array}{c}4.29 \\
(<0.001)\end{array}$ & 0.083 & $\begin{array}{c}4.22 \\
(<0.001)\end{array}$ & $0.084^{* * *}$ & $\begin{array}{c}4.20 \\
(<0.001)\end{array}$ \\
\hline LEV & + & $0.019^{* * *}$ & $\begin{array}{c}2.69 \\
(0.009)\end{array}$ & $0.018^{* *}$ & $\begin{array}{c}2.64 \\
(0.011)\end{array}$ & $0.019^{* * *}$ & $\begin{array}{c}2.68 \\
(0.009)\end{array}$ & $0.020^{* * *}$ & $\begin{array}{c}2.72 \\
(0.009)\end{array}$ \\
\hline SIZE & - & -0.006 & $\begin{array}{l}-0.97 \\
(0.338)\end{array}$ & -0.007 & $\begin{array}{l}-1.01 \\
(0.318)\end{array}$ & -0.007 & $\begin{array}{l}-0.93 \\
(0.355)\end{array}$ & -0.007 & $\begin{array}{l}-0.96 \\
(0.342)\end{array}$ \\
\hline BETA & + & $0.032 *$ & $\begin{array}{c}1.71 \\
(0.093)\end{array}$ & 0.030 & $\begin{array}{c}1.59 \\
(0.118)\end{array}$ & $0.033 *$ & $\begin{array}{c}1.75 \\
(0.085)\end{array}$ & 0.034 * & $\begin{array}{c}1.77 \\
(0.082)\end{array}$ \\
\hline BIG & $?$ & -0.036 & $\begin{array}{l}-0.77 \\
(0.442) \\
\end{array}$ & -0.032 & $\begin{array}{l}-0.68 \\
(0.502) \\
\end{array}$ & -0.039 & $\begin{array}{c}-0.82 \\
(0.413) \\
\end{array}$ & -0.039 & $\begin{array}{c}-0.82 \\
(0.417) \\
\end{array}$ \\
\hline FOR & $?$ & -0.046 & $\begin{array}{l}-0.54 \\
(0.592)\end{array}$ & -0.051 & $\begin{array}{l}-0.60 \\
(0.548)\end{array}$ & -0.045 & $\begin{array}{l}-0.52 \\
(0.607)\end{array}$ & -0.043 & $\begin{array}{l}-0.50 \\
(0.622)\end{array}$ \\
\hline \multicolumn{2}{|c|}{ Obs (n) } & \multicolumn{2}{|c|}{66} & \multicolumn{2}{|c|}{66} & \multicolumn{2}{|c|}{66} & \multicolumn{2}{|c|}{66} \\
\hline \multicolumn{2}{|c|}{ Firms (n) } & \multicolumn{2}{|c|}{33} & \multicolumn{2}{|c|}{33} & \multicolumn{2}{|c|}{33} & \multicolumn{2}{|c|}{33} \\
\hline \multicolumn{2}{|c|}{ F-value } & \multicolumn{2}{|c|}{$6.05^{* * *}$} & \multicolumn{2}{|c|}{$6.02^{* * *}$} & \multicolumn{2}{|c|}{$6.06^{* * *}$} & \multicolumn{2}{|c|}{$6.04^{* * *}$} \\
\hline \multicolumn{2}{|c|}{ Adj R2 } & \multicolumn{2}{|c|}{$35.21 \%$} & \multicolumn{2}{|c|}{$35.11 \%$} & \multicolumn{2}{|c|}{$35.26 \%$} & \multicolumn{2}{|c|}{$35.19 \%$} \\
\hline
\end{tabular}

Notes: The definition of variables can be referred to in Table $1 ; * * *, * *, *$ respectively indicate a significance level of $1 \%, 5 \%$ or $10 \% ;{ }^{1}$ COC $=\alpha_{0}+\alpha_{1}$ SRIdummy $+\alpha_{2}$ BM $+\alpha_{3}$ LEV $+\alpha_{4}$ SIZE $+\alpha_{5}$ BETA $+\alpha_{6}$ BIG $+\alpha_{7}$ FOR $+\varepsilon$

Table 6 shows the result of a comparative analysis which targeted those companies which were incorporated at the time of the change of the KRX SRI index to compare the costs of equity capital depending on the times of incorporation into the KRX SRI index with the control group's cost of equity capital. (Since the model's variance inflation factor (VIF) values are all below 2, it is believed that there were no problems with multi-collinearity.) The values of SRIdummy_Control, a coefficient value for incorporation into the KRX SRI index, had a significant positive (+) relation of $10 \%$ when COC $_{\text {MPEG }}$ and $\mathrm{COC}_{\mathrm{GM}}$ models were used. This is the same as the aforementioned result that companies which were incorporated at the time of change of component stocks experienced an increase in the cost of equity capital. In other words, it can be interpreted as the fact that investors were pessimistic about CSR activities.

Among the risk factors used as explanatory variables, the BM ratio, debt ratio, and company size all showed the expected relations. The BM ratio had a statistically significant positive (+) relation of $1 \%$ with the cost of equity capital, whereas the debt (LEV) ratio had a statistically significant positive (+) relation of $5 \%$ with the cost of equity capital. As seen above, this can be interpreted as the fact that if the BM ratio or the debt ratio is increased, the cost of equity capital is getting higher. In contrast, the company size (SIZE) had a significant negative $(-)$ relation of $1 \%$ with the costs of equity capital. It means that if the company size is getting bigger, it will reduce a reduction in the cost of equity capital.

Panel A in Table 7 shows the results of the analysis to verify Hypothesis 2. Panel B is the verification result of Hypothesis 2-1, and Panel $C$ is the verification result of Hypothesis 2-2. This is the result of analysis to assess the relation between the incorporation into the KRX SRI index and the corporate value estimated with Tobin's $Q$ by using Equation (6) in Table 7. (Since the model's variance inflation factor (VIF) values are all below 2 , it is believed that there were no problems with multi-collinearity.) The values of SRIdummy, a coefficient value for incorporation into the KRX SRI index, had no significant positive relation with all the implied costs of equity capital. This result is the same as the previous studies $[20,21]$. In other words, the incorporation into the KRX SRI index did not 
have influence on the corporate value. As the same with the aforementioned results, it can be either interpreted as the fact that investors did not believe that companies' CSR activities could contribute to enhancing corporate value, or be ascribed to the result of a mixed presence of optimists and pessimists about CSR activities. In addition, it can be also interpreted as the fact that the KRX SRI index might not correctly reflect companies' CSR activities.

Table 6. Results of Regression Analysis to Compare the Costs of Equity Capital. ${ }^{1}$

\begin{tabular}{|c|c|c|c|c|c|c|c|c|c|}
\hline \multirow[b]{2}{*}{ Variables } & \multirow{2}{*}{$\begin{array}{l}\text { Pred. } \\
\text { Sign }\end{array}$} & \multicolumn{2}{|c|}{$\mathrm{COC}_{\mathrm{AVG}}$} & \multicolumn{2}{|c|}{$\mathrm{COC}_{\mathrm{PEG}}$} & \multicolumn{2}{|c|}{$\mathrm{COC}_{\text {MPEG }}$} & \multicolumn{2}{|c|}{$\mathrm{COC}_{\mathrm{GM}}$} \\
\hline & & Coef. & $\begin{array}{c}t \text {-Stat. } \\
(p \text {-Value) }\end{array}$ & Coef. & $\begin{array}{c}t \text {-Stat. } \\
(p \text {-Value) }\end{array}$ & Coef. & $\begin{array}{c}t \text {-Stat. } \\
(p \text {-Value })\end{array}$ & Coef. & $\begin{array}{c}t \text {-Stat. } \\
(p \text {-Value) }\end{array}$ \\
\hline Intercept & & $0.459 * * *$ & $\begin{array}{c}4.12 \\
(<0.001)\end{array}$ & $0.449 * * *$ & $\begin{array}{c}4.09 \\
(<0.001)\end{array}$ & $0.466^{* * *}$ & $\begin{array}{c}4.12 \\
(<0.001) \\
\end{array}$ & $0.464^{* * *}$ & $\begin{array}{c}4.08 \\
(<0.001) \\
\end{array}$ \\
\hline $\begin{array}{l}\text { SRIdummy } \\
\text { Control }\end{array}$ & - & 0.020 & $\begin{array}{c}1.61 \\
(0.111)\end{array}$ & 0.017 & $\begin{array}{c}1.44 \\
(0.156)\end{array}$ & $0.021 *$ & $\begin{array}{c}1.68 \\
(0.097)\end{array}$ & $0.021 *$ & $\begin{array}{c}1.70 \\
(0.094)\end{array}$ \\
\hline $\mathrm{BM}$ & + & $0.048^{* * *}$ & $\begin{array}{c}3.47 \\
(0.001)\end{array}$ & $0.045^{* * *}$ & $\begin{array}{c}3.25 \\
(0.002)\end{array}$ & $0.050^{* * *}$ & $\begin{array}{c}3.55 \\
(0.001)\end{array}$ & $0.050^{* * *}$ & $\begin{array}{c}3.54 \\
(0.001)\end{array}$ \\
\hline LEV & + & $0.015^{* *}$ & $\begin{array}{c}2.41 \\
(0.019)\end{array}$ & $0.016^{* *}$ & $\begin{array}{c}2.59 \\
(0.012)\end{array}$ & $0.015^{* *}$ & $\begin{array}{c}2.31 \\
(0.024)\end{array}$ & $0.015^{* *}$ & $\begin{array}{c}2.29 \\
(0.025)\end{array}$ \\
\hline SIZE & - & $-0.018^{* * *}$ & $\begin{array}{l}-3.22 \\
(0.002)\end{array}$ & $-0.017^{* * *}$ & $\begin{array}{l}-3.20 \\
(0.002)\end{array}$ & $-0.018^{* * *}$ & $\begin{array}{c}-3.22 \\
(0.002)\end{array}$ & $-0.018^{* * *}$ & $\begin{array}{l}-3.19 \\
(0.002)\end{array}$ \\
\hline \multicolumn{2}{|c|}{ Obs (n) } & \multicolumn{2}{|c|}{74} & \multicolumn{2}{|c|}{74} & \multicolumn{2}{|c|}{74} & \multicolumn{2}{|c|}{74} \\
\hline \multicolumn{2}{|c|}{ Firms (n) } & \multicolumn{2}{|c|}{37} & \multicolumn{2}{|c|}{37} & \multicolumn{2}{|c|}{37} & \multicolumn{2}{|c|}{37} \\
\hline \multicolumn{2}{|c|}{ F-value } & \multicolumn{2}{|c|}{$5.15^{* * *}$} & \multicolumn{2}{|c|}{$4.95^{* * *}$} & \multicolumn{2}{|c|}{$5.23 * * *$} & \multicolumn{2}{|c|}{$5.17^{* * *}$} \\
\hline \multicolumn{2}{|c|}{ Adj R2 } & \multicolumn{2}{|c|}{$18.53 \%$} & \multicolumn{2}{|c|}{$17.81 \%$} & \multicolumn{2}{|c|}{$18.81 \%$} & \multicolumn{2}{|c|}{$18.61 \%$} \\
\hline
\end{tabular}

Notes: The definition of variables can be referred to in Table $1 ;{ }^{* * *}, * *, *$ respectively indicate a significance level of $1 \%, 5 \%$ or $10 \% ;{ }^{1} \mathrm{COC}=\alpha_{0}+\alpha_{1}$ SRIdummy_control $+\alpha_{2} \mathrm{BM}+\alpha_{3} \mathrm{LEV}+\alpha_{4} \mathrm{SIZE}+\varepsilon$.

Table 7. Results of Regression Analysis to Verify Hypothesis 2. ${ }^{1}$

\begin{tabular}{|c|c|c|c|c|c|c|c|}
\hline \multirow[b]{2}{*}{ Variables } & \multirow{2}{*}{$\begin{array}{l}\text { Pred. } \\
\text { Sign }\end{array}$} & \multicolumn{2}{|c|}{ Panel A } & \multicolumn{2}{|c|}{ Panel B } & \multicolumn{2}{|c|}{ Panel C } \\
\hline & & Coef. & $\begin{array}{c}t \text {-Stat. } \\
(p \text {-Value) }\end{array}$ & Coef. & $\begin{array}{c}t \text {-Stat. } \\
(p \text {-Value) }\end{array}$ & Coef. & $\begin{array}{c}t \text {-Stat. } \\
(p \text {-Value })\end{array}$ \\
\hline Intercept & & $7.33^{* * *}$ & $\begin{array}{c}7.83 \\
(<0.001)\end{array}$ & $7.506^{* * *}$ & $\begin{array}{c}6.76 \\
(<0.001)\end{array}$ & $7.684^{* * *}$ & $\begin{array}{c}4.40 \\
(<0.001)\end{array}$ \\
\hline SRIdummy & - & 0.066 & $\begin{array}{c}0.63 \\
(0.532)\end{array}$ & 0.169 & $\begin{array}{c}1.28 \\
(0.203)\end{array}$ & -0.057 & $\begin{array}{c}-0.35 \\
(0.726)\end{array}$ \\
\hline $\mathrm{BM}$ & + & $-0.528 * * *$ & $\begin{array}{c}-4.70 \\
(<0.001)\end{array}$ & $-0.553^{* * *}$ & $\begin{array}{c}-4.10 \\
(<0.001)\end{array}$ & $-0.865^{* * *}$ & $\begin{array}{l}-3.48 \\
(0.001)\end{array}$ \\
\hline LEV & + & 0.017 & $\begin{array}{c}0.43 \\
(0.666)\end{array}$ & -0.028 & $\begin{array}{l}-0.62 \\
(0.537)\end{array}$ & $0.210^{* *}$ & $\begin{array}{c}2.35 \\
(0.022)\end{array}$ \\
\hline SIZE & - & $-0.282^{* * *}$ & $\begin{array}{c}-5.95 \\
(<0.001)\end{array}$ & $-0.273^{* * *}$ & $\begin{array}{c}-4.91 \\
(<0.001)\end{array}$ & $-0.331^{* * *}$ & $\begin{array}{l}-3.68 \\
(0.001)\end{array}$ \\
\hline BETA & + & 0.151 & $\begin{array}{c}0.99 \\
(0.321)\end{array}$ & 0.104 & $\begin{array}{c}0.52 \\
(0.601)\end{array}$ & $0.460 *$ & $\begin{array}{c}1.92 \\
(0.060)\end{array}$ \\
\hline BIG & $?$ & -0.279 & $\begin{array}{c}-0.72 \\
(0.475) \\
\end{array}$ & -0.440 & $\begin{array}{c}-0.85 \\
(0.400)\end{array}$ & 0.311 & $\begin{array}{c}0.52 \\
(0.608)\end{array}$ \\
\hline FOR & $?$ & $2.092^{* * *}$ & $\begin{array}{c}3.94 \\
(<0.001) \\
\end{array}$ & $1.593^{* *}$ & $\begin{array}{c}2.55 \\
(0.012) \\
\end{array}$ & $1.948^{* *}$ & $\begin{array}{c}1.78 \\
(0.081) \\
\end{array}$ \\
\hline \multicolumn{2}{|c|}{ Obs (n) } & \multicolumn{2}{|c|}{172} & \multicolumn{2}{|c|}{106} & \multicolumn{2}{|c|}{66} \\
\hline \multicolumn{2}{|c|}{ Firms (n) } & \multicolumn{2}{|c|}{86} & \multicolumn{2}{|c|}{53} & \multicolumn{2}{|c|}{33} \\
\hline \multicolumn{2}{|c|}{ F-value } & \multicolumn{2}{|c|}{$18.21^{* * *}$} & \multicolumn{2}{|c|}{$15.92^{* * *}$} & \multicolumn{2}{|c|}{$5.98^{* * *}$} \\
\hline \multicolumn{2}{|c|}{ Adj R2 } & \multicolumn{2}{|c|}{$41.33 \%$} & \multicolumn{2}{|c|}{$49.86 \%$} & \multicolumn{2}{|c|}{$34.90 \%$} \\
\hline
\end{tabular}

Notes: The definition of variables can be referred to in Table $1 ; * * *, * * *$ respectively indicate a significance level of $1 \%, 5 \%$ or $10 \% ;{ }^{1}$ Tobin $\mathrm{Q}=\alpha_{0}+\alpha_{1}$ SRIdummy $+\alpha_{2}$ BM $+\alpha_{3}$ LEV $+\alpha_{4}$ SIZE $+\alpha_{5}$ BETA $+\alpha_{6}$ BIG $+\alpha_{7}$ FOR $+\varepsilon$ 


\section{Conclusions}

The study verified the relationships between the incorporation into the KRX SRI index and the cost of equity capital or corporate value of a company. Many previous studies provided the result that CSR activities could decrease the cost of equity capital by reducing information asymmetry. In the same context, this study classified those companies incorporated into the KRX SRI index as a group of businesses which were presumed to have a better CSR performance, and divided the times of incorporation into the KRX SRI index into three phases-the entire period, the introduction period, and the change period of the component stocks-in order to assess the effects of the incorporation into the index on the cost of equity capital and corporate value before and after companies were incorporated into the index. In addition, a group of companies similar to those incorporated into the index was selected as the control group for a comparative analysis on the cost of equity capital between the two groups.

The major results of the empirical analysis are as follows: first, the entire sample companies did not show a significant relation between the incorporation into the KRX SRI index and the cost of equity capital. Second, those incorporated into the KRS SRI index at the time of introduction showed a negative (-) relation with the cost of equity capital. Third, those incorporated into the KRS SRI index at the time of change of the component stocks showed a positive (+) relation with the cost of equity capital. Fourth, there was no statistically significant relation between corporate value change and the inclusion in the Social Responsibility Index.

These results can be attributed to a mixed presence of pessimistic and optimistic investors about CSR activities, or there is a possibility that the KRX SRI index might not accurately reflect companies' CSR activities.

The limitations of this study are as follows. First, the number of samples used for this study and the length of the study period, were limited. If a longer and more sufficient analysis period and a sufficient number of samples can be secured in the future, a more solid conclusion can be drawn. Especially if a sufficient number of sample companies which were incorporated due to the change of component stocks can be obtained, it will be more possible to analyze significant differences between the experimental group and the control group. Second, this study targeted only the KRX SRI index for analysis, but if a further study is to be extended beyond the KRX SRI index to the KRX SRI Eco index and the KRX SRI Governance index, a more meaningful result can be achieved. Third, if the features of those companies which are excluded from the KRX SRI index can be verified, it can be possible to find out intriguing differences between the incorporated group and the excluded group.

Acknowledgments: This work was supported by Hankuk Un iversity of Foreign Studies Research Fund of 2016.

Author Contributions: Kijung Eom and Giseok Nam conceived and designed the study; Kijung Eom Collected data and analyzed them. Giseok Nam discussed the implications and gave comments for publication.

Conflicts of Interest: The authors declare no conflict of interest.

\section{References}

1. Eurosif. European SRI Study 2008; Report; Eurosif: Brussels, Belgium, 2008.

2. Swanson, D.L. Toward an integrative theory of business and society: A research strategy for corporate social performance. Acad. Manag. Rev. 1999, 24, 506-521.

3. Paine, L.S. Value Shift; McGraw-Hill: New York, NY, USA, 2002.

4. Pava, M.; Krausz, J. The association between corporate social responsibility and financial performance: The paradox of social cost. J. Bus. Ethics 1996, 15, 321-357. [CrossRef]

5. José, A.; Patrice, L. A Meta-Analytical Investigation of the Relationship Between Corporate Social and Financial Performance. Rev. Fr. Gest. Ressour. 2005, 57, 18-40.

6. Posnikoff, J. Disinvestment from South Africa: They Did Well by Doing Good. Contemp. Econ. Policy 1997, 15, 76-86. [CrossRef] 
7. Waddock, S.A.; Graves, S.B. The corporate social performance-financial performance link. Strateg. Manag. J. 1997, 8, 303-319. [CrossRef]

8. Orlitzky, M.; Schmidt, F.L.; Rynes, S.L. Corporate Social and Financial Performance: A Meta-Analysis. Organ. Stud. 2003, 24, 403-441. [CrossRef]

9. Kim, C. Corporate Social Responsibility and Corporate Value. Korea Secur. Assoc. 2010, 38, 507-545.

10. Jang, J.; Choi, H. The Relation between Corporate Social Responsibility (CSR) and Financial Performance. Korean Acad. Assoc. Bus. Adm. 2010, 23, 633-648.

11. Wright, P.; Ferris, S. Agency Conflict and Corporate Strategy: The Effect of Divestment on Corporate Value. Strateg. Manag. J. 1997, 18, 77-83. [CrossRef]

12. Brammer, S.; Brooks, C.; Pavelin, S. Corporate Social Performance and Stock Returns. Financ. Manag. 2005, 35, 97-116. [CrossRef]

13. Lambert, R.; Leuz, C.; Verrecchia, R.E. Accounting Information, Disclosure, and The Cost of Capital. J. Account. Rev. 2007, 45, 385-420.

14. Ghoul, S.E.; Chuck, C.Y.; Mishra, R. Does corporate social responsibility affect the cost of capital? J. Bank. Financ. 2011, 35, 2388-2406. [CrossRef]

15. Cheon, M. Influence of Corporate Social Responsibility Activities on Cost of Equity Capital. Korea Account. Inform. Assoc. 2012, 30, 289-312.

16. Na, Y.; Im, W.; Kim, M. An Empirical Analysis on ESG Performance Information and Cost of Debt Capital. Korea Account. Inform. Assoc. 2013, 31, 453-487.

17. Jin, H.H.; Mitchell, O.S.; Piggott, J. Socially Responsible Investment in Japanese Pension. Pac.-Basin Financ. J. 2006, 14, 427-438. [CrossRef]

18. Becchetti, L.; Ciciretti, R.; Hansan, I. Corporate Social Responsibility and Shareholder's Value: An Event Study Analysis; Working Paper; Federal Reserve Bank of Atlanta: Atlanta, GA, USA, 2007.

19. Schroeder, M. Is there a Difference? The Performance Characteristics of SRI Equity Indices. J. Bus. Financ. Account. 2007, 31, 331-348. [CrossRef]

20. Ziegler, A. Is it beneficial to be included in a sustainability stock index? A panel data study for European firms. Environ. Resour. Econ. 2012, 52, 301-325. [CrossRef]

21. Oberndorfer, U.; Schmidt, P.; Wagner, M.; Ziegler, A. Does the stock market value the inclusion in a sustainability stock index? An event study analysis for German firms. J. Environ. Econ. Manag. 2013, 66, 497. [CrossRef]

22. Lee, S. Analysis of Performance of SRI index. Korean J. Financ. Eng. 2011, 10, 123-140.

23. Park, J. Performance of SRI in the Korean stock market: With focus on KRX SRI Index. Int. Area Stud. Rev. 2013, 17, 267-288. [CrossRef]

24. Park, J.; Ok, Y. Influence of Incorporation into the KRX SRI Eco on Corporate Value. Logos Manag. Stud. 2013, 11, 17-36.

25. Lee, Y.; Go, J. Effect of Corporate Social Responsibility on the Cost of Equity Capital and Information Asymmetry. Korean Account. J. 2013, 22, 159-193.

26. Choi, M. Relation between Corporate Social Responsibility, Governance Structure, and Cost of Capital. Korea Int. Account. Assoc. 2013, 51, 335-356.

27. Feldman, S.J.; Soyka, P.A.; Ameer, P.G. Does improving a firm's environmental management system and environmental performance result in a higher stock price? J. Investing. 1997, 6, 87-97. [CrossRef]

28. Dhaliwal, D.; Li, O.Z.; Tsang, A.H.; Yang, Y.G. Voluntary non-financial disclosure and the cost of equity capital: The case of corporate social responsibility reporting. Account. Rev. 2011, 86, 59-100. [CrossRef]

29. Easton, P. PE Ratios, PEG Ratios, and Estimating the Implied Expected Rate of Return on Equity Capital. Account. Rev. 2004, 79, 73-95. [CrossRef]

30. Gode, D.; Mohanram, P. Inferring the cost of capital using the Ohlson-Juettner Model. Rev. Account. Stud. 2003, 8, 399-431. [CrossRef]

31. Hwang, Y.; Lee, W.; Im, S. Estimating the Cost of Capital in the Korean Stock Market. Korean Account. Rev. 2008, 33, 97-125.

32. Jo, J.; Jo, M. Influence of Information Asymmetry on Cost of Equity Capital. Korean J. Account. Rev. 2007, 12, 269-288.

33. Black, B.S.; Jang, H.; Kim, W. Does Corporate Governance Predict Firm' Market Values? Evidence from Korea. J. Law Econ. Organ. 2006, 22, 366-413. [CrossRef] 
34. Na, Y.; Hong, S. Influence of Performance by CSR activity on Corporate Value depending on Company Size. Korean Account. J. 2011, 20, 125-160.

35. Lee, J.; Kim, J. Study on Relationship between Corporate Governance, Social \& Environment Evaluation indexes, and Corporate Values. Korean J. Account. Rev. 2013, 18, 88-99.

36. Chung, K.H.; Pruitt, S.W. A simple approximation of Tobin's Q. Financ. Manag. 1994, 23, 70-74. [CrossRef]

37. Fama, E.F.; French, K.R. Industry costs of equity. J. Financ. Econ. 1997, 43, 153-193. [CrossRef]

38. Botosan, C.A.; Plumlee, M.A. Assessing alternative proxies for the expected risk premium. Account. Rev. 2005, 80, 21-53. [CrossRef]

39. Francis, J.; LaFond, R.; Olsson, P.; Schipper, K. The market pricing of accruals quality. J. Account. Econ. 2005, 39, 295-327. [CrossRef]

40. Frederick, W. Corporate social responsibility. In The Oxford Handbook of Corporate Social Responsibility; Oxford University Press: Oxford, UK, 2008; pp. 522-531.

41. Kim, S.; Jeong, Y.; Heo, B. The Effect of Ownership Structure on the Corporate Environmental Performance. Korea Account. Inform. Assoc. 2008, 26, 213-237.

(c) 2017 by the authors. Licensee MDPI, Basel, Switzerland. This article is an open access article distributed under the terms and conditions of the Creative Commons Attribution (CC BY) license (http:/ / creativecommons.org/licenses/by/4.0/). 